\title{
Gambaran Hasil CT-Scan Toraks pada Pasien Coronavirus Disease 2019 (COVID-19)
}

\author{
Claudia R. E. Malaru, ${ }^{1}$ Alfa G. E. Y. Rondo, ${ }^{2}$ Christilia G. Wagiu ${ }^{2}$
}

${ }^{1}$ Program Studi Pendidikan Dokter Fakultas Kedokteran Universitas Sam Ratulangi, Manado, Sulawesi Utara, Indonesia

${ }^{2}$ Bagian Radiologi Fakultas Kedokteran Universitas Sam Ratulangi, Manado, Sulawesi Utara, Indonesia

Email:claudiamalaru@yahoo.com

\begin{abstract}
Coronavirus disease 2019 (COVID-19) is an infectious disease caused by severe acute respiratory syndrome coronavirus 2 (SARS-CoV-2). Indonesia reported its first case in March 2, 2020. Cases are increasing and spreading rapidly throughout Indonesia. One of the main imaging modalities for examination of COVID-19 is chest computed tomography scan (CT-scan) which plays an important role in detection, evaluation of severity, and follow-up of disease course. This study was aimed to obtain the description of CT scan results in patients with COVID-19. This was a literature review study using three databases, namely Pubmed, ClinicalKey, and ScienceDirect. The keywords used were COVID-19 AND Chest CT. Based on inclusion and exclusion criteria, there were 10 literatures selected. It was found that chest $\mathrm{CT}$ results could accurately evaluate the features and extent of lung lesions. The typical CT-scan results were ground-glass opacities (GGO), GGO with mixed consolidation, adjacent pleural thickening, interlobular septal thickening, and air bronchogram. Based on age, sex, and comorbidities, there was not any significant differences in chest CT findings. In conclusion, GGO, air bronchogram, and consolidation were found in chest CT-scan of COVID-19 patients. Meanwhile, based on age, sex, and comorbidities there were no significant differences in chest CT-scan.
\end{abstract}

Keywords: COVID-19, chest CT-scan

\begin{abstract}
Abstrak: Coronavirus disease 2019 (COVID-19) merupakan suatu penyakit menular yang disebabkan oleh severe acute respiratory syndrome coronavirus 2 (SARS-CoV-2). Indonesia melaporkan kasus pertama pada tanggal 2 Maret 2020. Kasus meningkat dan menyebar dengan cepat di seluruh wilayah Indonesia. Salah satu modalitas pencitraan utama yang menjadi pilihan untuk pemeriksaan COVID-19 ialah Computed Tomography Scan (CT-scan) toraks yang berperan penting dalam deteksi, evaluasi keparahan, dan tindak lanjut perjalanan penyakit. Penelitian ini bertujuan untuk mengetahui gambaran hasil $C T$-scan pada pasien COVID-19. Jenis penelitian ialah literature review dengan pencarian data menggunakan tiga database yaitu Pubmed, ClinicalKey, ScienceDirect. Kata kunci yang digunakan yaitu COVID-19 AND Chest CT. Hasil seleksi berdasarkan kriteria inklusi dan eksklusi mendapatkan 10 literatur. Didapatkan hasil $C T$ scan toraks dapat secara akurat mengevaluasi fitur dan luas lesi paru dan CT-scan yang khas ialah ground-glass opacities (GGO), GGO dengan konsolidasi campuran, penebalan pleura yang berdekatan, penebalan septum interlobular, dan bronkogram udara. Pada temuan CT-scan toraks berdasarkan usia, dan jenis kelamin tidak didapatkan perbedaan bermakna. Simpulan penelitian ini ialah terdapat GGO, air bronchogram, dan konsolidasi pada CT-scan toraks pasien COVID19 sedangkan berdasarkan usia, jenis kelamin, dan komorbid tidak ditemukan perbedaan bermakna.
\end{abstract}

Kata kunci: COVID-19, CT-scan toraks 


\section{PENDAHULUAN}

Coronavirus disease 2019 (COVID-19) merupakan suatu penyakit menular yang disebabkan oleh severe acute respiratory syndrome coronavirus 2 (SARS-CoV-2). ${ }^{1}$ Pada Desember 2019, kasus pneumonia yang misterius pertama kali dilaporkan di Kota Wuhan, Provinsi Hubei, China. Sumber penularan kasus ini belum diketahui dengan pasti, tetapi kasus pertama kali dikaitkan dengan pasar ikan di Wuhan. ${ }^{2}$ Pada tanggal 30 Januari 2020 World Health Organization (WHO) telah menetapkan sebagai Kedaruratan Kesehatan Masyarakat yang meresahkan dunia. Indonesia melaporkan kasus pertama pada tanggal 2 Maret 2020. Jumlah kasus meningkat dan menyebar dengan cepat di seluruh wilayah Indonesia. Pada tanggal 11 Maret 2020, World Health Organization (WHO) telah menetapkan penyakit COVID-19 sebagai pandemi. ${ }^{1}$

Beberapa penelitian melaporkan Computed Tomography Scan/CT-scan toraks menunjukkan fitur pencitraan yang khas pada hampir semua pasien COVID-19. Sebuah studi terbaru menunjukkan kelainan CT-scan yang paling sering diamati pada pasien COVID-19 ialah ground-glass opacity (GGO) (73/80 kasus; 91\%), konsolidasi (50/80 kasus; 63\%) dan penebalan septum interlobular (47/80 kasus; $59 \%){ }^{3}$

Sebagai infeksi saluran pernapasan, pencitraan dada dengan CT-scan memainkan peran penting dalam deteksi, evaluasi keparahan, dan tindak lanjut perjalanan penyakit. CT-scan toraks telah terbukti sebagai teknik pilihan dalam pencitraan infeksi paru. ${ }^{4}$ Salah satu modalitas pencitraan utama yang menjadi pilihan untuk pemeriksaan COVID-19 ialah CT-scan toraks. $^{2}$

Mengingat sangat bermanfaatnya $C T$ scan toraks pada penderita COVID-19 maka penulis terdorong untuk membahsa lebih detil mengenai gambaran hasil CT-scan pada pasien dengan COVID-19.

\section{METODE PENELITIAN}

Penelitian ini dilaksanakan dalam bentuk literature review terkait topik gam- baran hasil CT-scan toraks pada pasien COVID-19. Pencarian literatur yang tersedia abstrak dan full text melalui internet menggunakan database PubMed, Clinical Key, dan ScienceDirect. Kata kunci yang digunakan yaitu COVID-19 AND Chest CT. Seleksi literatur dilakukan berdasarkan kriteria inklusi dan eksklusi penelitian.

\section{HASIL PENELITIAN}

Hasil seleksi literatur berdasarkan kriteria inklusi dan eksklusi mendapatkan 10 literatur mengenai gambaran hasil $C T$ scan pada pasien COVID-19. Tabel 1 memperlihatkan hasil kajian dari masingmasing literatur.

Penelitian oleh Xia et $\mathrm{al}^{5}$ dilakukan di Rumah Sakit Anak, Wuhan, terhadap pasien laki-laki berusia 1-10 tahun dan pada pasien perempuan berusia 8-14 tahun. Kesemuanya memperlihatkan gambaran CT-scan toraks berupa GGO. Pada pasien perempuan berusia 8 tahun didapatkan gambaran GGO di lobus inferior paru kiri; dan pada pasien perempuan berusia 14 tahun didapatkan GGO yang tersebar di lobus inferior paru kanan, terletak subpleural atau meluas dari lesi subpleural.

Wang et $\mathrm{al}^{6}$ melakukan penelitian terhadap pasien laki-laki berusia 22-78 tahun dan pasien perempuan berusia 21 tahun. Kesemuanya memperlihatkan adanya gambaran GGO dengan beberapa variasi, berupa: GGO soliter; beberapa area GGO di bagian bawah bilateral lobus paru; GGO dengan dilatasi vaskular; GGO dengan bronkodilatasi vaskular; GGO yang tidak merata; GGO dengan vasodilatasi dan konsolidasi; dan GGO dengan halo sign di lobus kanan bawah.

Pada penelitian oleh Cui et $\mathrm{al}^{7}$ terhadap pasien laki-laki berusia 28-67 tahun dan pasien perempuan berusia 45-69 tahun didapatkan juga gambaran GGO yang bervariasi, berupa: GGO yang tidak merata (setelah 3 hari masuk rumah sakit/MRS) yang berlanjut peningkatan area GGO subpleural secara bilateral disertai dengan konsolidasi dan bayangan seperti kabel serta penebalan septum interlobular (setelah 6 hari MRS); GGO di sepanjang berkas vas- 
Tabel 1. Hasil kajian 10 literatur yang memenuhi kriteria inklusi dan eksklusi penelitrian

\begin{tabular}{|c|c|c|c|c|}
\hline No & Penulis/tahun & Sampel/usia & Komorbid & Hasil \\
\hline \multirow{4}{*}{1} & \multirow{4}{*}{$\begin{array}{l}\text { Xia et al, } \\
2020^{5}\end{array}$} & a. L: 1 tahun & - & GGO \\
\hline & & b. L: 10 tahun & - & GGO \\
\hline & & c. P: 8 tahun & - & GGO \\
\hline & & d. P: 14 tahun & - & GGO \\
\hline \multirow[t]{7}{*}{2} & \multirow{7}{*}{$\begin{array}{l}\text { Wang et al, } \\
2020^{6}\end{array}$} & a. L: 22 tahun & - & GGO \\
\hline & & b. L: 31 tahun & - & GGO \\
\hline & & c. L: 33 tahun & - & GGO \\
\hline & & d. L: 41 tahun & - & GGO \\
\hline & & e. L: 57 tahun & - & GGO \\
\hline & & f. L: 78 tahun & - & GGO, konsolidasi \\
\hline & & g. P: 21 tahun & - & GGO, halo sign \\
\hline \multirow[t]{5}{*}{3} & \multirow[t]{5}{*}{$\begin{array}{l}\text { Cui et al, } \\
2020^{7}\end{array}$} & a. L: 28 tahun & - & $\begin{array}{l}\text { GGO, konsolidasi, penebalan septum } \\
\text { interlobular }\end{array}$ \\
\hline & & b. L: 41 tahun & - & GGO \\
\hline & & c. L: 67 tahun & - & GGO \\
\hline & & d. P: 45 tahun & - & GGO \\
\hline & & e. P: 69 tahun & - & $\begin{array}{l}\text { GGO, konsolidasi, penebalan septum } \\
\text { interlobular }\end{array}$ \\
\hline \multirow[t]{6}{*}{4} & \multirow{6}{*}{$\begin{array}{l}\text { Zhu et al, } \\
2020^{8}\end{array}$} & a. L: 41 tahun & - & GGO, konsolidasi, air bronchogram \\
\hline & & b. L: 57 tahun & - & GGO, konsolidasi \\
\hline & & c. L: 61 tahun & - & GGO, pola retikuler \\
\hline & & d. L: 67 tahun & - & GGO, konsolidasi \\
\hline & & e. $P: 43$ tahun & - & GGO, konsolidasi \\
\hline & & f. P: 57 tahun & - & $\begin{array}{l}\text { GGO, konsolidasi, vakuola, penebalan } \\
\text { septum interlobular }\end{array}$ \\
\hline \multirow[t]{2}{*}{5} & \multirow[t]{2}{*}{ Gu et al, $2020^{9}$} & a. L: 46 tahun & - & GGO \\
\hline & & b. L: 70 tahun & - & GGO, penebalan interlobular \\
\hline \multirow[t]{3}{*}{6} & \multirow{3}{*}{$\begin{array}{l}\text { Li et al, } \\
2020^{10}\end{array}$} & a. L: 1,5 tahun & - & GGO \\
\hline & & b. L: 3 tahun & - & GGO \\
\hline & & c. L: 4 tahun & - & GGO \\
\hline \multirow[t]{4}{*}{7} & \multirow{4}{*}{$\begin{array}{l}\text { Steinberger et } \\
\text { al, } 2020^{11}\end{array}$} & a. L: 8 tahun & - & GGO \\
\hline & & b. L: 15 tahun & - & GGO, konsolidasi \\
\hline & & c. L: 18 tahun & - & GGO, konsolidasi \\
\hline & & d. P: 14 tahun & - & GGO, tanda halo sign \\
\hline \multirow[t]{2}{*}{8} & \multirow{2}{*}{$\begin{array}{l}\text { Zhang et al, } \\
2020^{12}\end{array}$} & 1. L: 20 tahun & - & GGO \\
\hline & & 2. L: 35 tahun & - & GGO, tanda bronkogram \\
\hline \multirow[t]{6}{*}{9} & \multirow{6}{*}{$\begin{array}{l}\text { Jiang et al, } \\
2020^{13}\end{array}$} & a. L: 66 tahun & - & GGO \\
\hline & & b. P: 57 tahun & - & GGO, konsolidasi \\
\hline & & c. P: 57 tahun & - & GGO, konsolidasi \\
\hline & & d. P: 65 tahun & - & GGO \\
\hline & & e. P: 67 tahun & - & GGO \\
\hline & & f. P: 86 tahun & - & GGO \\
\hline \multirow[t]{4}{*}{10} & \multirow{4}{*}{$\begin{array}{l}\text { Xie et al, } \\
2020^{14}\end{array}$} & \multirow[t]{4}{*}{49 sampel } & - Tipe ringan & GGO murni, konsolidasi, GGO dengan \\
\hline & & & tanpa komorbid & konsolidasi, fibrosis \\
\hline & & & $(\mathrm{n}=35)$ & GGO murni, konsolidasi, GGO dengan \\
\hline & & & $\begin{array}{l}\text { - Tipe parah } \\
\text { dengan komor- } \\
\text { bid }(\mathrm{n}=14)\end{array}$ & konsolidasi, fibrosis \\
\hline
\end{tabular}

Keterangan $: \mathrm{L}=$ laki-laki. $\mathrm{P}=$ Perempuan. $\mathrm{GGO}=$ Ground-glass opacities .

kular di daerah subpleural segmen lingula lobus kiri atas (setelah 2 hari MRS) yang berlanjut menjadi GGO yang meluas disertai konsolidasi, selanjutnya area lesi meningkat secara bermakna dengan peningkatan konsolidasi yang tidak merata (setelah 
9 hari /MRS), dan CT toraks setelah 15 hari MRS menunjukkan kepadatan GGO menurun; GGO tersebar di kedua paru; beberapa GGO subpleural bilateral dan setelah 7 hari MRS gambaran CT-scan toraks menunjukkan GGO difus bilateral dan subpleural yang melibatkan beberapa lobus paru; GGO yang tidak merata dan perubahan seperti jaringan secara bilateral di area subpleural dari pinggiran paru, $C T$-scan toraks diambil setelah 3 hari MRS menunjukkan peningkatan GGO yang tidak merata secara bilateral di pinggiran paru disertai dengan konsolidasi, GGO dan bayangan seperti jaringan di dalam paru disertai penebalan septum interlobular.

Pada penelitian oleh Zhu et $\mathrm{al}^{8}$ terhadap pasien laki-laki berusia 41-67 tahun dan pasien perempuan berusia 43-57 tahun didapatkan gambaran GGO yang bervariasi, berupa: GGO dengan konsolidasi di lobus kanan bawah, disertai air bronchogram; GGO dengan konsolidasi streak dan garis subpleural di paru kiri bawah; GGO yang terdistribusi di sekitar pinggiran dengan pola retikuler atau gambaran sarang lebah; GGO dengan konsolidasi beruntun yang terdistribusi di daerah perifer dan garis subpleural di lobus kanan atas; GGO perifer berbentuk bulat dengan sedikit konsolidasi di lobus kanan bawah; serta beberapa GGO yang tersebar di area perifer, GGO dengan konsolidasi di lobus bawah, GGO dengan gambaran vakuola di segmen atas paru kiri, dan GGO dengan penebalan septum interlobular di lobus inferior kanan.

Penelitian oleh Gu et al $^{9}$ terhadap pasien laki-laki berusia 46-70 tahun dan mendapatkan gambaran GGO pada lobus kanan disertai nodul; distribusi campuran bilateral dari GGO dengan kelainan yang terjadi secara bersamaan meliputi pola sarang lebah dan penebalan interlobular.

Penelitian oleh Li et al ${ }^{10}$ dilakukan pada pasien laki-laki berusia 1-4 tahun. Pada pasien laki-laki usia 1 tahun 5 bulan, CTscan toraks setelah 4 hari menunjukkan adanya GGO yang tidak merata pada lobus kanan atas, namun setelah 5 hari didapatkan penampilan menjadi normal. Demikian pula pada seorang pasien laki-laki berusia 3 tahun, CT-scan toraks setelah 9 hari gejala menunjukkan adanya GGO yang tidak merata di lobus kiri bawah, namun setelah 7 hari kemudian didapatkan tampilan normal. Hal yang serupa didapatkan juga pada seorang pasien laki-laki berusia 4 tahun, $C T$ scan toraks setelah 2 hari MRS memperlihatkan adanya GGO yang tidak merata di lobus kiri bawah, namun $C T$-scan toraks setelah 5 hari kemudian memperlihatkan tampilan normal.

Penelitian oleh Steinberger et $\mathrm{al}^{11}$ dilakukan pada pasien laki-laki berusia 8-18 tahun dan pasien perempuan berusia 14 tahun. Hasil penelitiannya mendapatkan gambaran GGO pada semua kasus dengan variasi untuk masing-masing kasus. Pasien laki-laki usia 8 tahun, CT-scan toraks menunjukkan GGO minimal pada lobus kanan bawah dan kiri dan tidak didapatkan konsolidasi. Pada seorang pasien laki-laki berusia 15 tahun, $C T$-scan toraks menunjukkan GGO bilateral dan konsolidasi dalam pola predominan perifer dan basilar yaitu pola yang dapat dilihat pada cedera paru dengan pengorganisasian akut. Pada seorang pasien laki-laki berusia 18 tahun, $C T$-scan toraks menunjukkan distribusi perifer dan basilar yang dominan dari GGO disertai area GGO di lobus kiri atas dengan konsolidasi perifer. Pada seorang pasien perempuan berusia 14 tahun, CT-scan toraks menunjukkan distribusi bilateral dan perifer dari GGO dengan tanda halo sign di lobus kiri bawah, sedangkan lobus atas dan lobus tengah kanan tidak menunjukkan kelainan.

Pada penelitian yang dilakukan oleh Zhang et $\mathrm{al}^{12}$ terhadap pada pasien laki-laki berusia 20-35 tahun. Hasil penelitiannya mendapatkan gambaran GGO pada semua kasus. Pada pasien laki-laki usia 20 tahun, CT-scan toraks menunjukkan GGO di paru kanan bawah, kemudian setelah 4 hari CTscan toraks menunjukkan peningkatan GGO. Pada pasien laki-laki berusia 35 tahun dengan $C T$-scan toraks yang menunjukkan lesi GGO dengan satu nodul padat kecil di dalamnya di lobus paru kiri bawah, dan setelah 5 hari $C T$-scan toraks menunjukkan peningkatan lesi dan tanda pembuluh darah membesar serta tanda bronkogram. 
Pada penelitian yang dilakukan oleh Jiang et al $^{13}$ terhadap pasien laki-laki berusia 66 tahun dan pasien perempuan berusia 5786 tahun. Didapatkan seorang pasien lakilaki usia 66 tahun $C T$-scan toraks pada hari ke-5 menunjukkan GGO dan setelah hari ke 11, 15, 19 dan 23 menunjukkan ukuran dan kepadatan lesi pada kedua paru secara bertahap dan bermakna menurun. Pada seorang pasien perempuan berusia 57 tahun, $C T$ scan toraks awal dilakukan pada hari pertama menunjukkan GGO multifokus dan konsolidasi kemudian setelah hari ke-7 dan 14 hari menunjukkan lesi paru sembuh secara bermakna. Pada seorang pasien perempuan berusia 57 tahun, $C T$-scan toraks awal dilakukan pada hari ke-4 menunjukkan GGO multifokus dan konsolidasi kemudian setelah hari ke-10 dan 20 menunjukkan lesi paru sembuh secara bermakna. Demikian pula pada seorang pasien perempuan berusia 65 tahun, $C T$-scan toraks dilakukan hari ke7 setelah onset penyakit menunjukkan GGO yang tidak merata terlihat di area subpleural lobus kanan bawah paru dan pada hari ke-15, CT-scan toraks menunjukkan lesi telah sembuh dengan jelas dan ukurannya berkurang. Pada seorang pasien laki-laki berusia 67 tahun, CT-scan toraks dilakukan hari ke8 setelah onset penyakit menunjukkan GGO yang tidak merata terlihat di area subpleural lobus kanan bawah paru dan pada hari ke-15, $C T$-scan toraks menunjukkan lesi telah sembuh dengan jelas dan ukurannya berkurang. Pada seorang pasien perempuan berusia 86 tahun $C T$-scan toraks awal dilakukan pada hari pertama menunjukkan GGO di daerah subpleural lobus kanan atas paru kemudian pada hari ke-7 CT-scan toraks menunjukkan ukuran lesi membesar dan GGO baru diamati di area subpleural lobus kiri atas paru yang artinya hasilnya telah berkembang, kemudian pada hari ke-27, CT-scan toraks menunjukkan kepadatan lesi menurun secara bermakna yang berarti hasilnya telah terjadi pengurangan, ${ }^{13}$

Pada penelitian oleh Linjun et $\mathrm{al}^{14}$ terhadap 49 pasien, 35 pasien tipe ringan tanpa komorbid, dan 14 pasien tipe parah dengan komorbid. Hasil CT-scan toraks memperlihatkan bahwa pada pasien dengan tipe ringan ditemukan GGO murni (34 pasien), konsolidasi (9 pasien), GGO dengan konsolidasi (19 pasien), dan fibrosis (15 pasien). Pada tipe parah ditemukan GGO murni (14 pasien), konsolidasi (4 pasien), GGO dengan konsolidasi (12 pasien), dan fibrosis (11 pasien). Pasien dengan tipe parah lebih cenderung menyandang penyakit hipertensi. CT-scan toraks menunjukkan tidak terdapat perbedaan bermakna antara tipe ringan dan tipe parah dengan adanya GGO murni pada 48 pasien. Pada pasien tipe parah, $C T$-scan toraks menunjukkan lebih banyak GGO dan konsolidasi dibandingkan pada pasien tipe ringan; selain itu pasien tipe parah memiliki lebih banyak fibrosis dibandingkan pasien tipe ringan.

\section{BAHASAN}

Hasil kajian literatur menunjukkan air bronchogram, konsolidasi, dan GGO merupakan fitur pencitraan yang paling sering dilaporkan. Pada penelitian ini didapatkan bahwa GGO merupakan temuan $C T$-scan toraks yang khas dengan morfologi bulat dan distribusi paru perifer, juga didapatkan GGO yang lebih luas dari pada konsolidasi. ${ }^{12}$ Salah satu penelitian menyatakan bahwa $C T$-scan toraks dapat secara akurat mengevaluasi fitur dan luas lesi paru. Pada penelitian itu juga dikatakan bahwa tanda $C T$-scan toraks yang khas ialah GGO, GGO dengan konsolidasi campuran, penebalan pleura yang berdekatan, penebalan septum interlobular, dan bronkogram udara. ${ }^{14}$

Pada pasien anak sampai dengan dewasa, CT-scan toraks dapat menunjukkan perubahan karakteristik. Umumnya pada anak ditemukan bentuk ringan karena tidak memiliki riwayat penyakit bawaan, dengan GGO unilateral atau bilateral. ${ }^{5}$ Penelitian lainnya melaporkan bahwa tidak terdapat perbedaan bermakna dari $C T$-scan toraks untuk pasien usia muda dan lanjut, tetapi pada pasien usia lanjut, $C T$-scan toraks menunjukkan rasio garis subpleural dan ketebalan pleura yang lebih tinggi dibandingkan pasien berusia muda, terlebih lagi seluruh lobus paru lebih mungkin dapat terlibat. $^{8}$

Berdasarkan jenis kelamin, temuan $C T$ - 
scan toraks menunjukkan bahwa tidak terdapat perbedaan bermakna antara kedua jenis kelamin. ${ }^{10}$ Penelitian ini juga mendapatkan bahwa tidak ada perbedaan bermakna berdasarkan jenis kelamin. Selain itu hasil menunjukkan bahwa fitur pencitraan mirip satu sama lain dan memiliki GGO bilateral dan perifer di paru. ${ }^{13}$

Temuan CT-scan toraks yang dilakukan jika ditinjau berdasarkan komorbid menunjukkan bahwa tidak terdapat perbedaan bermakna pada pasien dengan dan tanpa komorbid, namun, pasien dengan komorbid memiliki lebih banyak GGO dan konsolidasi dibandingkan pasien tanpa komorbid. ${ }^{14}$

\section{SIMPULAN}

Gambaran CT-scan toraks pada pasien COVID-19 memperlihatkan adanya air bronchogram, konsolidasi, dan ground-glass opacities. Tidak terdapat perbedaan bermakna dari gambaran CT-scan toraks berdasarkan usia, jenis kelamin, dan komorbid.

Diharapkan adanya penelitian lebih lanjut dan mendalam mengenai gambaran hasil CT-scan toraks yang lebih spesifik dengan komorbid seperti penyakit hipertensi, penyakit ginjal, dan penyakit hati.

\section{Konflik Kepentingan}

Penulis menyatakan tidak terdapat konflik kepentingan dalam studi ini.

\section{DAFTAR PUSTAKA}

1. Kementerian Kesehatan RI. Pedoman dan Pencegahan Coronavirus (COVID- 19). Jakarta: Kementerian Kesehatan Republik Indonesia, 2019; p. 4.

2. Susilo A, Rumende CM, Pitoyo CW, Santoso WD, Yulianti M, Herikurniawan H, et al. Coronavirus disease 2019: tinjauan literatur terkini. Journal Penyakit Dalam Indonesia. 2020;7(1):45.

3. Alsharif W, Qurashi A. Effectiveness of COVID-19 diagnosis and management tools: a review. Radiography. 2020; xxx $(\mathrm{xxxx}) \mathrm{xxx}$.

4. Tsou IYY, Liew CJY, Tan BP, Chou H, Wong SBS, Loke KSH, et al. Planning and coordination of the radiological res- ponse to the coronavirus disease 2019 (COVID-19) pandemic: the Singapore experience. Clin Radiol. 2020;75(6): 415-22.

5. Xia W, Shao J, Guo Y, Peng X, Li Z, Hu D. Clinical and CT Features in Pediatric Patients With COVID-19 Infection: Different Points From Adults. Pediatr Pulmonol. 2020;55(5):1169-74.

6. Wang J, Xu Z, Feng R, An Y, Ao W, Gao Y, et al. CT characteristics of patients infected with 2019 novel coronavirus: association with clinical type. Clin Radiol. 2020;75(6):408-14.

7. Cui N, Zou X, Xu L. Preliminary CT findings of coronavirus disease 2019 (COVID19). Clin Imaging. 2020;65(32):124-32.

8. Zhu T, Wang Y, Zhou S, Zhang N, Xia L. A Comparative study of chest computed tomography features in young and older adults with corona virus disease (COVID-19). Journal of Thoracic Imaging (JTI). 2020;35(4):W97-101.

9. Gu Q, Ouyang X, Xie A, Tan X, Liu J, Huang $F$, et al. A retrospective study of the initial chest CT Imaging findings in 50 covid-19 patients stratified by gender and age. J X-Ray Sci Technol. 2020; 28(5):875-84.

10. Li W, Cui H, Li K, Fang Y, Li S. Chest computed tomography in children with COVID-19. Pediatr Radiol. 2020;50(7): 1018.

11. Steinberger S, Lin B, Bernheim A, Chung M, Gao Y, Xie Z, et al. CT features of coronavirus disease (COVID-19) in 30 pediatric patients. Am J Roentgenol. 2020;215(6):1303-11.

12. Zhang L, Kong X, Li X, Zhu J, Liu S, Li W, et al. CT imaging features of 34 patients infected with COVID-19. Clin Imaging. 2020;68(April):226-31.

13. Jiang M, Chen P, Li T, Tang Y, Chen X, Chen $\mathrm{X}$, et al. Chest $\mathrm{CT}$ imaging features and clinical outcome of coronavirus disease 2019 (COVID-19): a single-center case study in Ningbo, China. Clin Imaging. 2021;69(May):27-32.

14. Xie L, Hou K, Xu H, Fu H, Xu R, Liu H, et al. Chest CT features and progression of patients with coronavirus disease 2019 . Br J Radiol. 2020;93(1116):20200219. 